\title{
A Complete Property Right Amendment
}

\author{
by \\ John Ryskamp
}

The drive beyond restriction of eminent domain use has finally produced a property right amendment. West Coast Hotel v. Parrish (1937), ${ }^{1}$ established the Constitutionality of health and welfare regulation in this country. That case said that such regulation was subject only to minimum scrutiny, that is, that it was Constitutional as long as it was rationally related to a legitimate government purpose. Other facts, such as freedom of speech, enjoy a high level of scrutiny, such that government may not undermine them unless the government action specifically fulfills an overriding government purpose. Unnoticed by either its proponents or its opponents, Proposition 90 went far beyond the usual anti-Kelo eminent domain reforms which restrict when eminent domain may be used. It even went beyond "Kelo plus" initiatives, which demand compensation not only for eminent domain takings, but also for land use regulations which reduce the value of real property. ${ }^{2}$ Proposition 90 overthrows the scrutiny regime and establishes an entirely new doctrine: every law maintains an important fact. Proposition 90 does not mention land use regulation, or regulation at all-it casts its net very widely: "government action."

Section 3, Paragraph 8 of the initiative states: "Except when taken to protect public health and safety, 'damage' to private property includes government actions that result in substantial economic loss to private property. Examples of substantial economic loss include, but are not limited to, the downzoning of private property, the elimination of any access to private property, and limitations on the use of private air space. 'Government action' shall mean any statute, charter provision, ordinance, resolution, law,

\footnotetext{
${ }^{1} 300$ US 379. This case allowed states to pass minimum wage laws, and stands for the proposition of blanket approval for government to formulate health and welfare regulations, a blanket approval which had been withheld prior to West Coast Hotel.

${ }^{2}$ For a brief introduction to the other initiatives, see The Thicket, September 27, 2006 (archived online at www.ncsl.typepad.com). The "Kelo plus" initiatives may be considered the flip side of so-called TABOR (taxpayer bill of rights) initiatives, which put a cap on state spending/taxing based on a formula measuring inflation and population growth - an attack on "government purpose" tax and spend power under minimum scrutiny, and an embryonic attempt to formulate factual indicia of both government and maintenance. The TABOR proposals have come in for much polemical—but not much scholarly—commentary. See a bibliography at www.legis.state.wi.us/lrb/pubs/tapthepower.htm. Colorado has been wrestling with the effects of its TABOR law for over a decade. See a summary at http://www.ncsl.org/programs/fiscal/taborpts.htm. Needless to say, the bond market was not amused by Colorado's TABOR law, and lowered its credit rating. See Dennis Hoffman and Timothy Hogan, "The Taxpayer's Bill of Rights: Evidence from Colorado and Implications for Arizona," http://wpcarey.asu.edu/seidman/reports/tabor.pdf. See also Iris J. Lav and Karen Lyons, "Maine's 'Taxpayer Bill of Rights' Proposal Fails to Fix Flaws of Colorado's TABOR," 40 State Tax Notes No. 2 (April 10, 2006); Therese J. McGuire and Kim S. Rueben, "The Colorado Revenue Limit: The Economic Effect of TABOR," 40 State Tax Notes No. 6 (May 8, 2006); Andrew Reschovsky, "The Taxpayer Bill of Rights (TSBO): A Solution to Wisconsin's Fiscal Problems or a Prescription for Future Fiscal Crises?" 33 State Tax Notes No. 4 (July 26, 2004).
} 
rule or regulation." ${ }^{3}$ The examples provide guidance if the government action relates to real property. But what if it doesn't? Proposition 90 relates to "private property," not merely to real property.

The broadest concept of property in American law is known as the "property interest," and under the Fourteenth Amendment its reach is extensive. ${ }^{4}$ For example:

Beyond employment the [Supreme] Court [has] found "legitimate entitlements" in a variety of situations....[S]tudents [are accorded] some due process hearing rights prior to suspending them, even for such a short period as ten days....[A cause of action for discrimination is] a property interest....Beyond statutory entitlements, the Court has looked to state decisional law to find that private utilities may not terminate service at will but only for cause, for nonpayment of charges, so that when there was a dispute about payment or the accuracy of charges, due process required the utility to follow procedures to resolve the dispute prior to terminating service.

So, if they lower your unemployment compensation — or end it-is that compensable under Proposition 90? Is an electricity rate increase? Is "education" a property interest, such that suspension is compensable? Is lack of health insurance compensable under Proposition 90? Housing eviction?

Proposition 90 puts power over facts into the hands of individuals, and takes that power out of the hands of the political system. At least in that regard, it is consistent with other anti-Kelo propositions. It is also consistent with American history, in which such facts as freedom of speech were regarded as intrinsic to the human experience and could only be distorted by - and distorting of - government. That's why they were removed from government. What facts? and, in what ways removed? Those are the questions we are going to have to answer under Proposition 90. But we will be asking and answering them, not the political system. Factual inquiry has replaced government discretion: that is the new equation of Proposition 90. For better or worse, we are on a new Constitutional road.

Washington's Initiative 933 made it clear that its compensation provision reached as far as the concept of property, to any type of regulation, and to a much higher level of scrutiny than minimum scrutiny. Indeed, it is a maintenance right to property:

To avoid damaging the use or value of private property, prior to enacting or adopting any ordinance, regulation, or rule which may damage the use or value of private property, an agency must consider and document: (a) The private property that will be affected by the action; (b) The existence and extent of any legitimate governmental purpose for the action; (c) The existence and extent of any nexus or link between any legitimate government interest and the action; (d) The extent to which the regulation's restrictions are proportional to any impact of a particular property on any legitimate government interest, in light of the impact of other properties on the same governmental interests; (e) The extent to which the action deprives property owners of economically viable uses of the property; (f) The extent to which the action derogates or takes away a fundamental attribute of property ownership, including, but not limited to, the right to exclude others, to possess, to beneficial use, to enjoyment, or to dispose of property; (g) The extent to which the action enhances or creates a publicly owned right in property; (h) Estimated compensation that may need to be paid under this act; and (i) Alternative means which are less

\footnotetext{
${ }^{3}$ The text and analysis of the Legislative Analyst are online at www.ss.ca.gov/elections.

${ }^{4}$ Board of Regents v. Roth, 408 US 564 (1972).

${ }^{5}$ This summary is provided at www.law.cornell.edu. Citations omitted.
} 
restrictive on private property and which may accomplish the legitimate governmental purpose for the regulation, including, but not limited to, voluntary conservation or cooperative programs with willing property owners, or other nonregulatory actions....For purposes of this act, the following definitions apply: "Private property" includes all real and personal property interests protected by the fifth amendment to the United States Constitution or Article I, section 16 of the state Constitution ${ }^{6}$ owned by a nongovernmental entity, including, but not limited to, any interest in land, buildings, crops, livestock, and mineral and water rights. ${ }^{7}$

The implications of this section are that maintenance of property is the mandated initial goal, and that the question of government with respect to property, is rarely if ever reached.

But now there was no scrutiny regime to answer the question, what in fact is property? by referring it to the political system - the procedure of the scrutiny regime. Thus, the new laws now inherited the immemorial ambiguity of the facts. The doctrine was explicit, but the facts were just as murky as ever. Nor was there any indication that public opinion would share the definition of property - whatever that was - which had motivated those who had drafted laws in the name of public opinion. Nor was there any indication that the drafters' restrictions were the extent of what public opinion demanded with respect to the facts. Were the advocates of these propositions, ready to govern?

In any event, on the basis of these propositions it is possible to formulate a property right which captures the trend of the "Kelo plus" initiatives:

Section 1. Eminent domain or regulation of any property interest shall not be exercised unless it specifically fulfills an overriding government purpose, and shall be compensated at the full value of such exercise.

Section 2. Congress shall have the power to enforce this article by appropriate legislation.

\footnotetext{
6 "Private property shall not be taken for private use, except for private ways of necessity, and for drains, flumes, or ditches on or across the lands of others for agricultural, domestic, or sanitary purposes. No private property shall be taken or damaged for public or private use without just compensation having been first made, or paid into court for the owner, and no right-of-way shall be appropriated to the use of any corporation other than municipal until full compensation therefor be first made in money, or ascertained and paid into court for the owner, irrespective of any benefit from any improvement proposed by such corporation, which compensation shall be ascertained by a jury, unless a jury be waived, as in other civil cases in courts of record, in the manner prescribed by law. Whenever an attempt is made to take private property for a use alleged to be public, the question whether the contemplated use be really public shall be a judicial question, and determined as such, without regard to any legislative assertion that the use is public: Provided, That the taking of private property by the state for land reclamation and settlement purposes is hereby declared to be for public use."

${ }^{7}$ The text of the initiative is online at www.secstate.wa.gov/elections/initiatives/text/i933.pdf.
} 